\title{
Versatility of a Multicommuted Flow System in the Spectrometric Determination of Three Analytes
}

\author{
Gomes, P. R.; Lima, H. S.; Lima, A. J. D.; Fernandes, R. N.; Lyra, W. S.;* \\ Cunha, F. A. S.; Silva, E. F.; Ferreira, M. L. B.; Lima, W. S.
}

Rev. Virtual Quim., 2017, 9 (2), 563-574. Data de publicação na Web: 24 de março de 2017

http://rvq.sbq.org.br

\begin{abstract}
Versatilidade de um Sistema em Fluxo Multicomutado na Determinação Espectrofotométrica de Três Analitos
\end{abstract}

Resumo: Neste trabalho foi desenvolvido um sistema de multicomutação em fluxo para a determinação de diclofenaco de sódio, ácido acetilsalicílico e fluoretos em injetáveis, comprimidos e águas de torneira, respectivamente. Para o diclofenaco de sódio, o método usado foi baseado em sua reação com permanganato de potássio $\left(20-80 \mathrm{mg} \mathrm{L}^{-1}\right)$.Para o ácido acetilsalicílico, o método usado foi baseado na reação de Trinder após hidrólise alcalina do analito (25-100 mg L ${ }^{-1}$ ). Para os íons fluoreto, o método usado foi o bem conhecido SPADNS $\left(0,4-1,6 \mathrm{mg} \mathrm{L}^{-1}\right)$. Os resultados foram comparados com seus respectivos métodos de referência e, aplicando o teste- $t$ emparelhado, nenhuma diferença estatisticamente significativa foi verificada entre eles ao nível de confiança de 95\%. Após a otimização das variáveis do sistema analítico, ele foi capaz de analisar 80, 72 e 68 amostras $\mathrm{h}^{-1}$ contendo diclofenaco de sódio, ácido acetilsalicílico e fluoretos, respectivamente com geração de resíduos reduzida de acordo com os princípios básicos da química verde.

Palavras-chave: Sistema de injeção em fluxo; multicomutação; injetáveis; comprimidos; águas de torneira.

\begin{abstract}
In this work was developed a multicommuted flow system for determination of sodium diclofenac, acetylsalicylic acid and fluoride ions in ampoules, tablets and tap waters, respectively. For sodium diclofenac the method used was based on its reaction with potassium permanganate $\left(20-80 \mathrm{mg} \mathrm{L}^{-}\right.$ $\left.{ }^{1}\right)$. For acetylsalicylic acid the method used was based on Trinder's reaction after alkaline hydrolysis of the analyte ( 25 - $100 \mathrm{mg} \mathrm{L}^{-1}$ ). For fluoride ions the method used was the well-known SPADNS (0.4 - $1.6 \mathrm{mg} \mathrm{L}^{-1}$ ). Results were compared with their respective reference methods and, by applying the paired $t$-test, no statistic difference between them was verified at the $95 \%$ confidence level. After

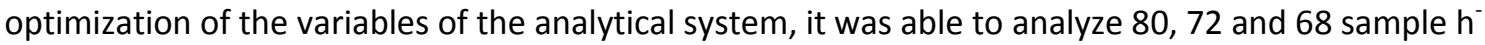
${ }^{1}$ containing sodium diclofenac, acetylsalicylic acid and fluoride, respectively with reduced waste generation according to basic principles of green chemistry.
\end{abstract}

Keywords: Flow-injection system; multicommutation; ampoules; tablets; tap waters.

\footnotetext{
* Universidade Federal da Paraíba, Departamento de Química, Campus I, CEP 58051-970, João PessoaPB, Brazil.

Mspectru@gmail.com

DOI: $10.21577 / 1984-6835.20170033$
}

Rev. Virtual Quim. |Vol 9| | No. 2| |563-574| 


\section{Versatility of a Multicommuted Flow System in the Spectrometric Determination of Three Analytes}

Paulo Roberto B. Gomes, ${ }^{\mathrm{a}}$ Helson S. de Lima, ${ }^{\mathrm{a}}$ Anderson de Jesus D. Lima, ${ }^{a}$ Ridvan N. Fernandes, ${ }^{a}$ Wellington S. Lyra, ${ }^{b}, *$ Francisco Antônio S. Cunha, ${ }^{b}$ Eduardo F. Silva, ${ }^{a}$ Marcos Leandro B. Ferreira, ${ }^{c}$ Wanderson S. de Lima $^{a}$

\footnotetext{
${ }^{a}$ Universidade Federal do Maranhão, Departamento de Química, Campus do Bacanga, CEP 65080-540, São Luís-MA, Brazil.

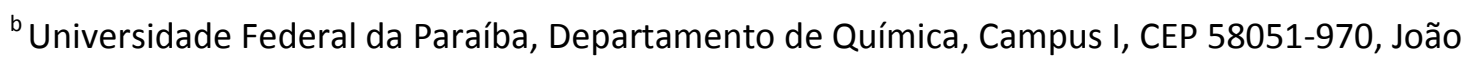
Pessoa-PB, Brazil.

c Instituto Federal de Educação Ciência e Tecnologia do Maranhão, Campus Zé Doca, CEP 65365-000, Zé Doca-MA, Brazil.

*spectru@gmail.com
}

Recebido em 15 de março de 2016. Aceito para publicação em 24 de março de 2017

1. Introduction

2. Material and methods

2.1. Reagents and solutions

2.2. Samples

2.3. Multicommutation system

2.4. Multicommutation analytical methods

2.5. Multicommutation procedure

2.6. Reference methods

\section{Results and discussion}

3.1. Optimization of the muticommutation system

3.2. Analytical curves and figures of merit

3.3. Analytical determinations

\section{Conclusions}

\section{Introduction}

As consequence of strict regulations, the pharmaceutical industry is now seeking development of fast, less expensive and accurate analytical methodologies. ${ }^{1}$ These new methodologies aim to: guarantee drug content, identify adulterants in pharmaceutical formulations which represent health risks, ${ }^{2}$ and reduce (or replace) Rev. Virtual Quim. |Vol 9| |No. 2| |563-574| 
materials harmful to human health and environment. ${ }^{3}$ In this sense, flow systems are excellent tools for dealing with solutions in wet chemical analysis. ${ }^{4}$ Among them, Multicommuted Flow Analysis (MCFA) can be considered an evolution of the flow injection concept towards Green Analytical Chemistry $(\mathrm{GAC}){ }^{5}$ since the addition of the reagent to the sample zone occurs only in a strict amount when required in the analytical procedure. ${ }^{4,6}$ MCFA design uses solenoid valves on binary sampling operation mode that makes its operation straightforward, very versatile, robust and enables the development of green analytical methodologies with low consumption of reagents and samples.

MCFA is a hot trend in automation and its principles can be applied in all kinds of measurements. Literature repports several techniques using MCFA and among them spectroanalytical (molecular spectrophotometry, chemiluminescence, fluorescence, atomic spectrometry and vibrational spectrometry) are often chosen by researchers as strategies; ${ }^{8}$ followed by electroanalytical. ${ }^{7}$ In terms of applications, environmental analysis is the main field, followed by food and beverages, pharmaceutical, biochemical and industrial using sample dilution, titrations, separation/concentration, sample stopping, sequential/ simultaneous determinations and miscellaneous .

Sodium diclofenac is the sodium salt of 2[(2,6-dichlorophenyl)amino] benzene acetic acid and is relatively safe and effective nonsteroidal anti-inflammatory drug (NSAID)with pronounced anti-rheumatic, antiinflammatory, analgesic and antipyretic properties. $^{9}$ Sodium diclofenac inhibits reversibly Cyclooxygenases $(\mathrm{COX})^{10}$ enzymes and consequently the biosynthesis of prostaglandins. Most of prostaglandins are enzymatically derived from arachidonic acid by the metabolic pathway of the "arachidonic acid cascade" which is associated with inflammatory processes. ${ }^{11}$

2-acetoxy-benzoic acid is the systematic name (IUPAC) for acetylsalicylic acid (ASA), more popularly known as aspirin. This is one of the oldest medicines, and play an important role in modern therapeutics with use for headaches, fever, muscular pain, and inflammations due to arthritis or injury. ${ }^{12}$ ASA acts as an acetylating agent of the serine residue in the active site of the prostaglandin-endoperoxide synthase enzyme (PTGS) which inhibits irreversibly the synthesis of prostaglandin and thromboxanes. ${ }^{13,14}$

Fluoride $\left(F^{-}\right)$ions occur in almost all waters and its presence cause significant effects in human beings drinking it ${ }^{15-18}$ especially the control and diminution of dental caries. ${ }^{19}$ After ingestion fluoride ions are readily transmitted through the bloodstream and deposited in mineralized tissues such as bones and teeth. The effectiveness of fluoride ions in preventing dental caries is due to three factors: (i) strengthening of the dental enamel by reducing its solubility to the acid attack, inhibiting demineralization, (ii) favoring of the remineralization and (iii) changing and decreasing the number and cariogenic potential of microorganisms. ${ }^{20}$

The goal of the present paper is to propose a unique multicommuted flow analyzer which is able to determine sodium diclofenac in ampoules, ASA in tablets and fluoride $\left(F^{-}\right)$ions in tap waters by changing only operational parameters for three different reactions. The choice of analytical determinations previously mentioned have been motivated by the importance these analytes share.

\section{Material and methods}

\subsection{Reagents and solutions}

All chemicals were of analytical grade and water recently deionized by a Milli-Q (Millipore) system was employed throughout.

For determination of sodium diclofenac: Stock solution of $1000 \mathrm{mg} \mathrm{L}^{-1}$ sodium diclofenac (Sigma, St. Louis, MO, USA) was 
prepared dissolutioning a suitable amount of the salt in deionized water. The calibration solutions with five levels of concentration of sodium diclofenac $\left(20.0-80.0 \mathrm{mg} \mathrm{L}^{-1}\right)$ were prepared by suitable dilution from stock solutions in deionized water. An approximately $0.3 \mathrm{mmol} \mathrm{L}^{-1} \mathrm{KMnO}_{4}$ (Merck, Darmstadt, Germany) solution was prepared by dissolution of suitable amount of the salt in approximately $100.0 \mathrm{mmol}^{-1} \quad \mathrm{H}_{2} \mathrm{SO}_{4}$ (Merck, Darmstadt, Germany) aqueous solution. Deionized water was used as carrier solution.

For determination of ASA: Stock solution of $1000 \mathrm{mg} \mathrm{L}^{-1} \mathrm{ASA}$ (Sigma, St. Louis, MO, USA) was prepared by dissolution of suitable amount of the acid in $10.0 \mathrm{~mL}$ of $1.0 \mathrm{~mol} \mathrm{~L}^{-1}$ $\mathrm{NaOH}$ (Merck, Darmstadt, Germany) solution followed by heating during 10 minutes for complete hydrolysis and the volume was up to $250 \mathrm{~mL}$ with deionized water. The calibration solutions with five levels of concentration of ASA $\left(25.0-100.0 \mathrm{mg} \mathrm{L}^{-1}\right)$ were prepared by suitable dilution from stock solutions in deionized water. The Trinder's reagent was prepared dissoluting of $1.0 \mathrm{~g}$ of $\mathrm{Fe}\left(\mathrm{NO}_{3}\right)_{3} \cdot 9 \mathrm{H}_{2} \mathrm{O}$ (Merck, Darmstadt, Germany) in deionized water and the volume was up to $100 \mathrm{~mL}$. An approximately 100.0 $\mathrm{mmol} \mathrm{L}^{-1} \mathrm{HNO}_{3}$ (Merck, Darmstadt, Germany) solution was used as carrier solution.

For determination of fluoride ions: Stock solution of $100 \mathrm{mg} \mathrm{L}^{-1}$ fluoride was prepared by dissolution of suitable amount of the $\mathrm{NaF}$ (Sigma, St. Louis, MO, USA) in deionized water. The calibration solutions with five levels of concentration of fluoride (0.4 - 1.6 $\mathrm{mg} \mathrm{L}^{-1}$ ) were prepared by suitable dilution from stock solutions in deionized water. The zirconium-SPADNS reagent was prepared by dissolution of suitable amount of $\mathrm{ZrOCl}_{2}$. $8 \mathrm{H}_{2} \mathrm{O}$ (Merck, Darmstadt, Germany) and SPADNS (1,8-Dihydroxy-2-(4sulfophenylazo)naphthalene-3,6-disulfonic acid trisodium salt) (Sigma, St. Louis, MO, USA) in $4.0 \mathrm{~mol} \mathrm{~L}^{-1} \mathrm{HCl}$ (Merck, Darmstadt, Germany) aqueous solution. Deionized water was used as carrier solution.

\subsection{Samples}

Five brands of ampoules drugs with a nominal content of $25 \mathrm{mg} \mathrm{mL}^{-1}$ of sodium diclofenac and five brands of tablets with a nominal content of $500 \mathrm{mg}$ of ASA were purchased from local drugstores. Five tap water samples were collected in five points in the city of São Luís, Maranhão, Brazil.

Ampoules samples, before analysis, were only suitably diluted in deionized water in order to read analytical signals in the linear response of the method.

Twenty tablets containing ASA were grinded in a mortar to yield a fine powder and the average mass of them was dissolved in $10 \mathrm{~mL}$ of $1.0 \mathrm{~mol} \mathrm{~L}^{-1} \mathrm{NaOH}$ solution and boiled for 10 minutes for complete hydrolysis. Afterwards, a filtration to remove the insoluble particles was performed with ash less filter paper (Whatman $n^{\circ} 40$ ). The resulting solution was diluted to a final volume $(100 \mathrm{~mL})$ with deionized water. This solution was suitably diluted in deionized water in order to read analytical signals in the linear response of the method.

Tap water samples were collected and preserved according to American Public Health Association recommendations to determine fluoride in water samples. ${ }^{21}$ Before analysis were added $0.5 \%\left(w^{-1}\right)$ sodium arsenite, $\mathrm{NaAsO}_{2}$ (Merck, Darmstadt, Germany) solution to remove residual chlorine interference, suitably filtered in order to remove eventual insoluble particles with ash less filter paper (Whatman $n^{\circ} 40$ ) and then evaporated up to $1 / 3$ of their initial volume.

\subsection{Multicommutation system}

Measurements were performed in a 700 Plus FEMTO spectrophotometer with quartz cells with $1 \mathrm{~cm}$ of optical path. The multicommutation system depicted in Figure 1 (a)comprises three three-way solenoid 
valves 161 T031 (NResearch Inc., West Caldwell, USA) and a IPC-8 peristaltic pump (Ismatec, Zurich, Switzerland) with polyethylene pumping tubes (i.d. $=0.8 \mathrm{~mm}$ ) propulsion system. The different components of the multicommuted flow system were connected with polyethylene tubing (i.d. = $0.8 \mathrm{~mm})$ and a reaction coil $(50,60$ and $75 \mathrm{~cm}$ for sodium diclofenac, ASA and fluoride ions, respectively) was made with the same polyethylene tube. A four-way homemade confluence connector in acrylic was also used. Control of the analytical system, data acquisition and processing were carried out by means of a Pentium II microcomputer running a software written in QuickBasic Version 4.5. A PCL711S (Advantech corp. Ohio, USA) interface was used to generate control signals of the solenoid valves which were sent to power interface based on UNL2803 integrated circuit.

(a)

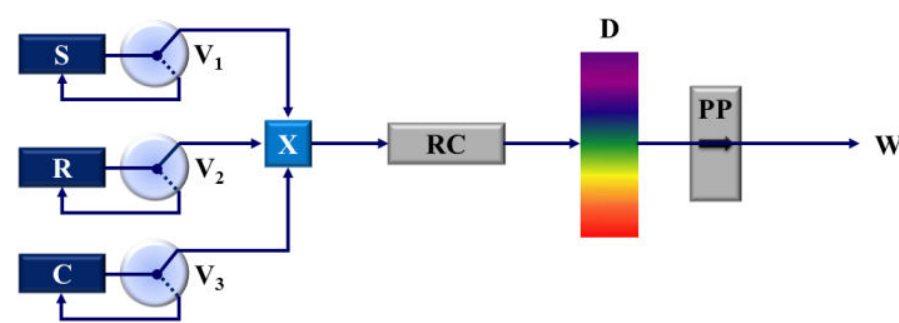

(b)

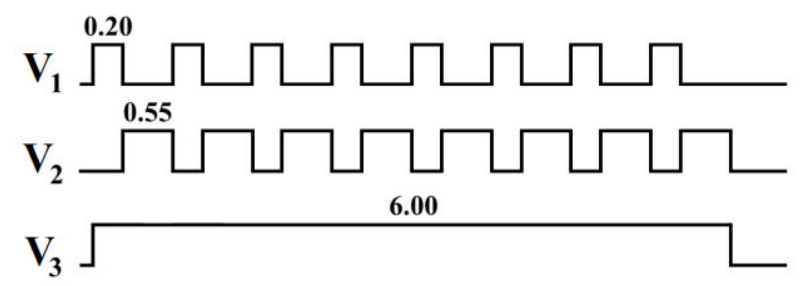

(c)
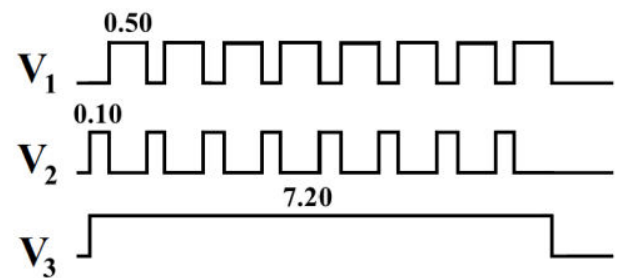

(d)

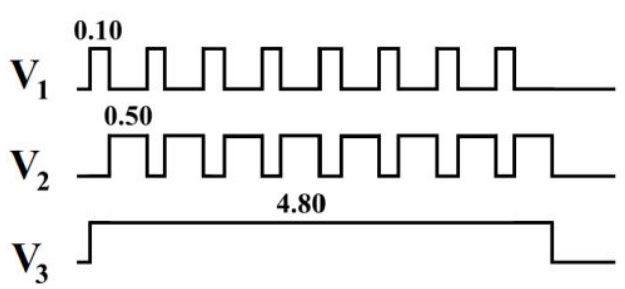

Figure 1. (a) Schematic diagram of the multicommutation system, (b) Sodium diclofenac, (c) ASA and (d) fluoride determination time diagrams for the samples. $V_{1}, V_{2}, V_{3}$ - Solenoid valves; $\mathrm{S}$ - sample; $\mathrm{R}$ - reactant; $\mathrm{C}$ - carrier fluid; PP - peristaltic pump; $\mathrm{M}$ - Mixing zone (reactor); D detector; $\mathrm{X}$ - confluence point; $\mathrm{W}$ - waste. For determination of sodium diclofenac: $\mathrm{R}$, potassium permanganate; $C$, deionized water. For determination of ASA: $R$, Trinder's reagent; C, $0.1 \mathrm{~mol} \mathrm{~L}^{-1} \mathrm{HNO}_{3}$ aqueous solution. For determination of fluoride: $\mathrm{R}, \mathrm{SPANDS}+\mathrm{ZrOCl}_{2} ; \mathrm{C}$, deionized water. Time intervals (in seconds) $T_{1}, T_{2}$ and $T_{3}$ correspond to $V_{1}, V_{2}$ and $V_{3}$ valves respectively 


\subsection{Multicommutation procedure}

Three three-way solenoid valves $\left(V_{1}, V_{2}\right.$, and $V_{3}$ ) assessment to the system was enabled by the sample and reagents: $V_{1}$ for the sample (S), while $V_{2}$ and $V_{3}$ inserted the reactant $(R)$ and carrier fluid $(C)$, respectively.

In the analytical cycles as presented in Figure 1(b), (c) and (d) all valves are switched off and the carrier solution (C) is aspirated through solenoid valve $\mathrm{V}_{3}$ towards detector in order to obtain the baseline. Afterwards, $V_{1}, V_{2}$ and $V_{3}$ are switched on, but $V_{1}$ and $V_{2}$ are alternately switched on while $V_{3}$ remains always switched on up to a defined number of cycles (Figure 1 (b), (c) and (d)) and then all valves are switched off. This sequence of actions alternately inserts in the analytical course defined amounts of sample and reactant which are directed towards the confluence $(X)$ and reaction coil $(R C)$.

\subsection{Multicommutation methods}

For determination of sodium diclofenac: in aqueous solution, potassium permanganate reacts with sodium diclofenac in acid medium to produce $\mathrm{Mn}^{2+}$ ions which exhibits maximum absorbance at $450 \mathrm{~nm}$. The absorbance is proportional to sodium diclofenac concentration on the sample. Semi reactions are showed in Figure 2 (a).
For determination of ASA: a first step of alkaline hydrolysis is carried out in order to produce salicylate ions. The excess of is $\mathrm{NaOH}$ is neutralized and the salicylate ions react with $\mathrm{Fe}$ (III) ion to produce a 1:3 violet complex with maximum absorption at 525 $\mathrm{nm}$ (Trinder's reaction), as showed in Figure 2 (b).

For determination of fluoride: first step zirconium reacts with SPADNS to produce a zirconium-dye lake. Then, fluoride ions react with the zirconium-dye lake, dissociating a portion of it into a colorless complex anion $\left(\left[\mathrm{ZrF}_{6}\right]^{2-}\right)$ and the dye (maximum absorption at $570 \mathrm{~nm}$ ) showed in Figure 2 (c). As the amount of fluoride increases, the color produced becomes progressively lighter. ${ }^{21}$

\subsection{Reference methods}

According to Brazilian pharmacopoeia, ${ }^{22}$ the reference methods for determinating sodium diclofenac and ASA are based on direct UV spectrophotometric measurements at $258 \mathrm{~nm}$ in methanol medium (solvent/blank) and acid-base back titration using phenol red as indicator respectively. For determination of fluoride the reference method is the SPADNS which is based on spectrophotometric measurements at $570 \mathrm{~nm}$ in aqueous solution (solvent/blank). ${ }^{21}$ 
(a)

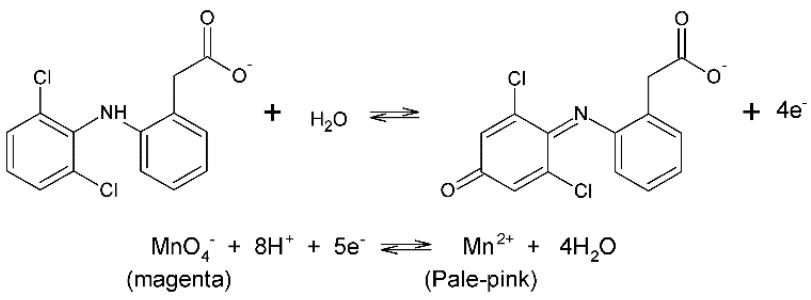

(b)
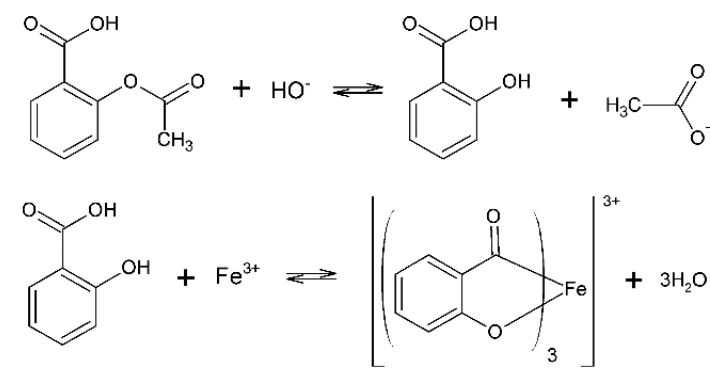

(colorless) (Yellow/brown)

(Violet)

(c)

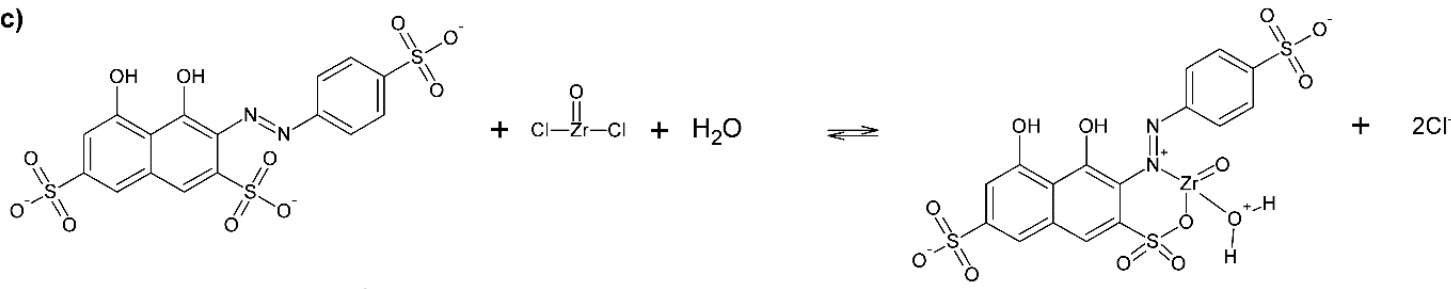

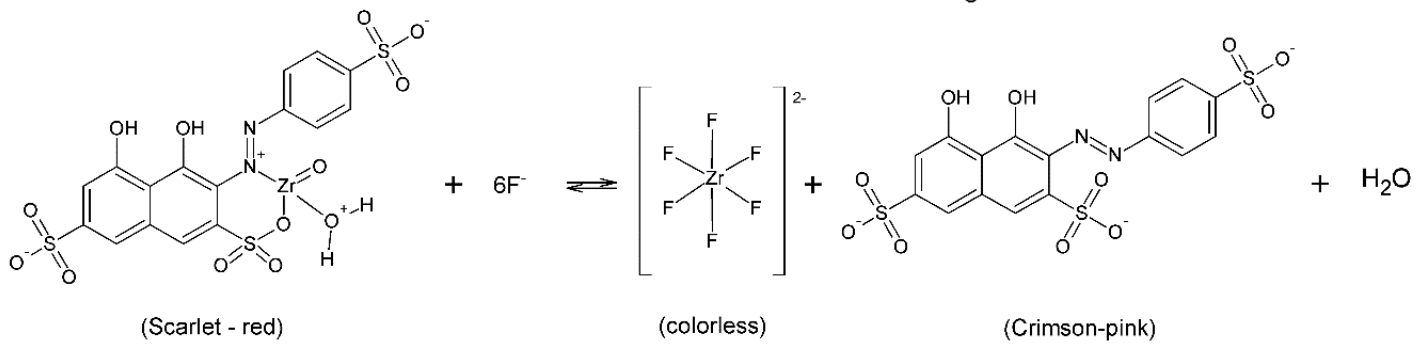

Figure 2. Reactions for determination of: (a) sodium diclofenac, ASA (b) and (c) fluoride ions

\section{Results and discussion}

\subsection{Optimization of multicommutation} system

Opening time of $\mathrm{V}_{1}$ and $\mathrm{V}_{2}$, flow rate, concentration of reactant and carrier fluid, number of cycles and coil length have been optimized through means of univariate method. The influence of each variable in the absorbance of a defined standard solution on the analysis is observed through a variable variation in a defined range. This procedure was carried out aiming to find the combination of factors which provide the best compromise between sensitivity and reproducibility of the analytical signal, as well reach lower values of limit of detection (LOD) and limit of quantification (LOQ). For each analyte these factors have been evaluated in different ranges and a unique value was chosen as showed in Table 1. 
Table 1. Selected parameters for the proposed multicommutation system

\begin{tabular}{|c|c|c|c|}
\hline Analyte & Parameter & Evaluated range & Selected value \\
\hline \multirow{7}{*}{$\begin{array}{l}\text { Sodium } \\
\text { diclofenac }^{\mathrm{a}}\end{array}$} & $\mathrm{V}_{1}$ time $(\mathrm{s})$ & $0.20-0.50$ & 0.20 \\
\hline & $\mathrm{V}_{2}$ time $(\mathrm{s})$ & $0.25-0.55$ & 0.35 \\
\hline & Flow rate $\left(\mathrm{mL} \mathrm{min}^{-1}\right)$ & $2.5-4.0$ & 3.5 \\
\hline & Reactant $\left(\mathrm{mol} \mathrm{L}^{-1}\right)$ & $(1.0-4.0) \times 10^{-4}$ & $3.0 \times 10^{-4}$ \\
\hline & Carrier fluid $\left(\mathrm{mol} \mathrm{L}^{-1}\right)$ & - & - \\
\hline & Number of cycles & $6-12$ & 8 \\
\hline & Reaction coil $(\mathrm{cm})$ & $0.10-0.50$ & 100 \\
\hline \multirow{7}{*}{$\mathrm{ASA}^{\mathrm{b}}$} & $\mathrm{V}_{1}$ time $(\mathrm{s})$ & $0.10-0.70$ & 0.50 \\
\hline & $\mathrm{V}_{2}$ time $(\mathrm{s})$ & $0.10-0.50$ & 0.10 \\
\hline & Flow rate $\left(\mathrm{mL} \mathrm{min}^{-1}\right)$ & $2.5-4.0$ & 3.5 \\
\hline & Reactant $\left(\mathrm{mol} \mathrm{L}^{-1}\right)$ & $0.05-0.4$ & 0.1 \\
\hline & Carrier fluid $\left(\mathrm{mol} \mathrm{L}^{-1}\right)$ & $0.01-0.4$ & 0.1 \\
\hline & Number of cycles & $8-14$ & 12 \\
\hline & Reaction coil $(\mathrm{cm})$ & $60-120$ & 80 \\
\hline \multirow{8}{*}{ Fluoride $^{c}$} & $\mathrm{~V}_{1}$ time $(\mathrm{s})$ & $0.30-0.50$ & 0.50 \\
\hline & $\mathrm{V}_{2}$ time $(\mathrm{s})$ & $0.10-0.30$ & 0.10 \\
\hline & Flow rate $\left(\mathrm{mL} \mathrm{min}^{-1}\right)$ & $1.0-4.0$ & 2.8 \\
\hline & $\left.{ }^{2}\right)^{-1}$ & $(1.68-3.36) \times 10^{-3 d}$ & $3.36 \times 10^{-3 d}$ \\
\hline & Reactant (mol L') & $(0.40-1.66) \times 10^{-3 e}$ & $1.66 \times 10^{-3 e}$ \\
\hline & Carrier fluid $\left(\mathrm{mol} \mathrm{L}^{-1}\right)$ & - & - \\
\hline & Number of cycles & $8-14$ & 8 \\
\hline & Reaction coil $(\mathrm{cm})$ & $50-125$ & 75 \\
\hline
\end{tabular}

\subsection{Analytical curves and figures of merit}

A linear relationship between the absorbance (analytical response) and the concentrations of the analyte in the calibration solutions was observed for the three cases. The confidence intervals of the calibration model parameters $(\widehat{y}=\alpha+\beta X)$ at the $95 \%$ confidence level for the three analytes are shown in Table 2. Since the confidence intervals for estimated parameters of the calibration models contain the "zero", they are considered statistically significant. ${ }^{23}$

Table 2. Confidence intervals for the parameters of the linear model and figures of merit for each analyte

\begin{tabular}{ccccc}
\hline \multirow{2}{*}{ Analyte } & \multicolumn{2}{c}{$\begin{array}{c}\text { Confidence intervals for the parameters of the } \\
\text { model }(\widehat{y}=\boldsymbol{\alpha}+\boldsymbol{\beta})\end{array}$} & \multicolumn{2}{c}{$\begin{array}{c}\text { Values of merit figures } \\
\left(\times \mathbf{~ 1 0}^{-1} \mathrm{mg} \mathrm{L}^{-1}\right)\end{array}$} \\
\cline { 2 - 5 } & $\boldsymbol{\alpha} \pm \boldsymbol{t}_{13} \boldsymbol{s}(\boldsymbol{\alpha})$ & $\boldsymbol{\beta} \pm \boldsymbol{t}_{13} \mathbf{s}(\boldsymbol{\beta})$ & LOD & LOQ \\
\hline Sodium diclofenac & $-0.0767 \pm 0.0008$ & $0.0108 \pm 4.43 \times 10^{-6}$ & 0.10 & 0.33 \\
ASA & $0.0090 \pm 0.0002$ & $0.0061 \pm 9.29 \times 10^{-7}$ & 0.57 & 1.90 \\
Fluoride & $0.0040 \pm 0.0003$ & $0.1367 \pm 9.25 \times 10^{-5}$ & 0.02 & 0.07 \\
\hline
\end{tabular}


In order to validate the linear calibration models an analysis of variance (ANOVA) was done. For this purpose, the F-test for lack of fit and for significance of regression were applied. $^{24}$ The analytical curves were constructed based on three genuine repeated measurements in five levels of concentration. The values of regression, residual, lack of fit and pure error were calculated using the mean squares (MS) presented in Table 3.
In all cases, the values of $\mathrm{MS}_{\text {lof }} / \mathrm{MS}_{\text {pure error }}$ are smaller than the point of $F$-distribution at a $95 \%$ confidence level with equivalent freedom degrees ( 3 and 10 , respectively). This indicates that there is no evidence off it lack for linear models, in other words, a good fit. In all cases, the values of $\mathrm{MS}_{\text {regression }} / \mathrm{MS}_{\text {residual }}$ are much larger than the point of $F$-distribution at a $95 \%$ confidence level with equivalent degrees of freedom (1 and 13 , respectively). This indicates that the results of linear regressions are significant.

Table 3. Analysis of variance for the fit of a linear model $(\widehat{y}=\alpha+\beta X)$ of the analytical curves

\begin{tabular}{|c|c|c|c|c|c|}
\hline Analyte & Source & $\begin{array}{l}\text { Degrees of } \\
\text { freedom }\end{array}$ & $\begin{array}{l}\text { Mean square } \\
\text { (MS) }\end{array}$ & $\frac{\mathrm{MS}_{\text {lof }}^{\mathrm{c}}}{\mathrm{MS}_{\text {pure error }}}$ & $\frac{\mathrm{MS}_{\text {regression }}}{\mathrm{MS}_{\text {residual }}}$ \\
\hline \multirow{4}{*}{$\begin{array}{l}\text { Sodium } \\
\text { diclofenac }\end{array}$} & Regression & 1 & $7.87 \times 10^{-1}$ & \multirow{4}{*}{$1.97^{\mathrm{a}}$} & \multirow{4}{*}{$2.77 \times 10^{7 b}$} \\
\hline & Residual & 13 & $2.84 \times 10^{-8}$ & & \\
\hline & Lof $^{c}$ & 3 & $4.58 \times 10^{-8}$ & & \\
\hline & Pure error & 10 & $2.32 \times 10^{-8}$ & & \\
\hline \multirow{4}{*}{ ASA } & Regression & 1 & $3.92 \times 10^{-1}$ & \multirow{4}{*}{$1.35^{\mathrm{a}}$} & \multirow{4}{*}{$2.01 \times 10^{8 b}$} \\
\hline & Residual & 13 & $1.95 \times 10^{-9}$ & & \\
\hline & Lof $^{c}$ & 3 & $2.44 \times 10^{-9}$ & & \\
\hline & Pure error & 10 & $1.80 \times 10^{-9}$ & & \\
\hline \multirow{4}{*}{ Fluoride } & Regression & 1 & $5.05 \times 10^{-2}$ & \multirow{4}{*}{$1.55^{\mathrm{a}}$} & \multirow{4}{*}{$1.02 \times 10^{7 b}$} \\
\hline & Residual & 13 & $4.95 \times 10^{-9}$ & & \\
\hline & Lof $^{c}$ & 3 & $9.56 \times 10^{-9}$ & & \\
\hline & Pure error & 10 & $6.15 \times 10^{-9}$ & & \\
\hline
\end{tabular}

Since the analytical curves were validated (no lack of fit and significant regression), figures of merit were estimated according to IUPAC recommendation. ${ }^{25}$ Twenty measurements of the blank was used to estimate limit of detection (LOD) and limit of quantification (LOQ) for each analyte. Table 2 shows that the proposed method presented low values LOD and LOQ and good performance in terms of linear ranges of response.

\subsection{Analytical determinations}

After variables of the multicommuted system optimization, validation of the analytical curves and estimation of merit figures the proposed method was applied in the determination of sodium diclofenac, ASA and fluoride in ampoules, tablets and tap water, respectively. As presented inTable 4the proposed method and reference methods have yielded similar results in the determination of the three analytes. In fact, there is no statistic difference between the results through applying the paired $t$-test at the $95 \%$ confidence level was verified. The proposed method presented a precision as good as the reference method revealed by the closer values of overall relative standard 
deviation (R.S.D.) ( $\mathrm{n}=5$ ). This satisfactory precision can be ascribed to the optimization of the variables.

Table 5 presents selected analytical features of the proposed multicommutation system which represents a good performance in terms of LOD, overall R.S.D., working rage, sampling rate and consumption of reactants and samples when compared to batch reference methods.

Table 4. Results of the determinations of sodium diclofenac, ASA and fluoride by using proposed and reference methods

\begin{tabular}{ccc}
\hline Samples & Proposed Method & Reference Method \\
\hline Sodium diclofenac & $25 \mathrm{mg} \mathrm{mL}^{-1}$ & nominal content \\
$(1)$ & $24.9 \pm 0.1$ & $25.0 \pm 0.2$ \\
$(2)$ & $24.8 \pm 0.1$ & $24.7 \pm 0.1$ \\
$(3)$ & $24.9 \pm 0.2$ & $25.0 \pm 0.1$ \\
(4) & $24.9 \pm 0.1$ & $24.8 \pm 0.1$ \\
(5) & $24.7 \pm 0.2$ & $24.9 \pm 0.2$ \\
Overall R.S.D. (\%) & 0.60 & 0.62 \\
\hline ASA & $500 \mathrm{mg}^{2}$ nominal content \\
(1) & $497.4 \pm 1.9$ & $497.2 \pm 2.5$ \\
(2) & $495.1 \pm 1.5$ & $495.3 \pm 2.1$ \\
(3) & $498.6 \pm 1.6$ & $498.2 \pm 2.4$ \\
(4) & $496.0 \pm 1.7$ & $496.3 \pm 2.3$ \\
(5) & $499.0 \pm 1.8$ & $498.2 \pm 2.2$ \\
Overall R.S.D. (\%) & 0.34 & 0.47 \\
\hline Fluoride & & $\mathrm{mg} \mathrm{L}^{-1}$ \\
(1) & $0.33 \pm 0.02$ & $0.35 \pm 0.01$ \\
(2) & $0.34 \pm 0.01$ & $0.32 \pm 0.02$ \\
(3) & $0.13 \pm 0.02$ & $0.17 \pm 0.02$ \\
(4) & $0.35 \pm 0.01$ & $0.32 \pm 0.01$ \\
(5) & $0.21 \pm 0.01$ & $0.25 \pm 0.02$ \\
Overall R.S.D. (\%) & 5.45 & 5.76 \\
\hline
\end{tabular}

Table 5. Proposed multicommutation system analytical features for each analyte

\begin{tabular}{|c|c|c|c|}
\hline Parameter & Sodium diclofenac & ASA & Fluoride \\
\hline Working range $\left(\mathrm{mg} \mathrm{L}^{-1}\right)$ & $20-80$ & $25-100$ & $0.4-1.6$ \\
\hline Overall R.S.D. (\%) & 0.60 & 0.34 & 5.47 \\
\hline Sampling rate (sample $\mathrm{h}^{-1}$ ) & 80 & 72 & 68 \\
\hline Sample consumption (回) & 20.4 & 29.2 & 187.0 \\
\hline Reagent consumption (?]L) & 11.6 & 5.8 & 37.0 \\
\hline Carrier consumption (미) & 350.0 & 420.0 & 224.0 \\
\hline Waste generation (国) & 382.0 & 455.0 & 448.0 \\
\hline Method & $\begin{array}{l}\text { Permanganate's } \\
\text { reaction }\end{array}$ & Trinder's reaction & SPADNS' reaction \\
\hline Carrier fluid & Deionized water & $\begin{array}{l}100.0 \mathrm{mmol} \mathrm{L}^{-1} \\
\mathrm{HNO}_{3} \text { solution }\end{array}$ & Deionized water \\
\hline
\end{tabular}




\section{Conclusions}

This work demonstrated the viability of the use an unique multicommuted system determination of sodium diclofenac, ASA and fluoride in ampoules, tablets and tap waters, respectively. The binary way operation of the solenoid valves, which were inserted discrete volumes of sample and reagent, showed to be effective for determination of the three analytes. Its operation is easy and robust that makes possible to determine others analytes changing two parameters: the reaction coil (physical) and the number of cycles (operational). Emphazing the proposed system is not a "polyvalent system" is very important because variables should be optimized according to reactions used, even using the same manifold.

Variables optimization allowing fast homogenization, low consumption of sample and reagents and low waste generation according to basic principles of GAC. Moreover, provided analytical curves with suitable linear range of response and sensitivity as revealed by low values of LOD and LOQ, for accurate and precise determination of the three analytes. Unfortunately, there are not in literature others flow analyzers that use this paper's reactions to do a fair analytical performance comparison.

\section{Acknowledgements}

The authors thank the Brazilian agencies CNPq and CAPES for scholarship.

\section{References}

${ }^{1}$ Song, Z. ; Zhang, N. In vitro detecting ultratrace novalgin in medicine and human urine by chemiluminescence. Talanta 2003, 60, 161. [CrossRef] [PubMed]
${ }^{2}$ Weinert, P. L.; Pezza, L. ; Pezza, H. R. A simplified reflectometric method for the rapid determination of dipyrone in pharmaceutical formulations. Journal of the Brazilian Chemical Society 2007, 18, 846. [CrossRef]

${ }^{3}$ Anastas, P. T. Green chemistry and the role of analytical methodology development. Critical Reviews in Analytical Chemistry 1999, 29, 167. [CrossRef]

${ }^{4}$ Rocha, F. R. P. ; Reis, B. F. ; Zagatto, E. A. G.; Lima, J. L. F. C.; Lapa, R. A. S.; Santos, J. L. M. Multicommutation in flow analysis: concepts, applications and trends. Analytica Chimica Acta 2002, 468, 119. [CrossRef]

${ }^{5}$ Lavorante, A. F.; Pires, C. K.; Reis, B. F. Multicommuted flow system employing pinch solenoid valves and micro-pumps: spectrophotometric determination of paracetamol in pharmaceutical formulations. Journal of Pharmaceutical and Biomedical Analysis 2006, 42, 423. [CrossRef] [PubMed]

${ }^{6}{ }^{6}$ Melchert, W. R.; Reis, B. F.;Rocha, F. R. P. Green chemistry and the evolution of flow analysis. A review.Analytica Chimica Acta2012,714, 8.[CrossRef] [Pubmed]

${ }^{7}$ Morales-Rubio, A.; Reis, B. F.; de la Guardia, M. Multi-commutation in spectrometry. Trends in Analytical Chemistry 2009, 28, 903. [CrossRef]

${ }^{8}$ Feres, M. A.; Fortes, P. R.; Zagatto, E. A. G.; Santos, J. L. M.; Lima, J. F. L. C. Multicommutation in flow analysis: Recent developments and applications. Analytica Chimica Acta 2008, 618, 1. [CrossRef] [PubMed]

${ }^{9}$ Rocha, R. S.; Beati, A. A. G. F.; Oliveira, J. G.; Lanza, M. R. V. Avaliação da degradação do diclofenaco de sódio utilizando $\mathrm{H}_{2} \mathrm{O}_{2}$ /fentonem reator eletroquímico. Química Nova 2009, 32, 354. [Link]

${ }^{10}$ Issa, M. M.; Nejem, R. M.; Al-Kholy, M.; ElAbadla, N. S.; Helles, R. S.; Saleh, A. A. An indirect atomic absorption spectrometric determination of ciprofloxacin, amoxicillin and diclofenac sodium in pharmaceutical formulations. Journal of the Serbian Chemical Society 2008, 73, 569. [CrossRef] 
${ }^{11}$ Voet, D.; Voet, J. G.; Pratt, C. W.; Fundamentals of Biochemistry, $4^{\text {th }}$ ed., Wiley: New Jersey, 2013.

${ }^{12}$ Satori, E. R.; Medeiros, R. A.; Rocha-Filho, R. C.; Fatibello-Filho, O. Square-wave voltammetric determination of acetylsalicylic acid in pharmaceutical formulations using boron-doped diamond electrode without the need of previous alkaline hydrolysis step. Journal of the Brazilian Chemical Society 2009, 20, 360. [CrossRef]

${ }^{13}$ Vane, J. R. Inhibition of prostaglandin synthesis as a mechanism of action for aspirin-like drugs. Nature New Biology 1971, 231, 232. [CrossRef] [PubMed]

${ }^{14}$ Hamberg, M.; Svensson, J. Samuelsson, B. Thromboxanes: a new group of biologically active compounds derived from prostaglandin endoperoxides. Proceedings of the National Academy of Sciences of the United States of America 1975, 72, 2994. [PubMed]

${ }^{15}$ Dar, M.; Sankar, K.; Dar, I. Fluorine contamination in groundwater: a major challenge. Environmental Monitoring and Assessment 2011, 173, 955. [CrossRef] [PubMed]

${ }^{16}$ WHO; Fluoride in Drinking-Water, IWA Publishing: London, 2006. [Link]

${ }^{17}$ Maliyekkal, S. M.; Shukla, S.; Philip, L.; Nambi, I. M. Enhanced fluoride removal from drinking water by magnesia-amended activated alumina granules. Chemical
Engineering Journal 2008, 140, 183. [CrossRef]

${ }^{18}$ Qin, X.; Wang, S.; Yu, M.; Zhang, L.; Li, X.; Zuo, Z.; Zhang, X.; Wang, L. Child skeletal fluorosis from indoor burning of coal in southwestern China. Journal of Environmental and Public Health 2009, 2009, 1. [CrossRef] [PubMed]

${ }^{19}$ Bond, A. M.; Murray, M. M. Direct titrimetric determination of fluoride in natural waters. Biochemistry Journal 1953, 53, 642. [CrossRef] [PubMed]

${ }^{20}$ Brasil. Fundação Nacional da Saúde; Manual de Fluorentação da Água para Consumo Humano, Funasa: Brasília, 2012.

${ }^{21}$ Clesceri, L. S.; Greenberg, A. E.; Eaton, A. D.; Standard Methods for the Examination of Water and Wastewater, $20^{\text {th }}$ Edn., American Public Health Association: Washington, 1998.

${ }^{22}$ Brasil. Agência Nacional de Vigilância Sanitária/Fundação Oswaldo Cruz; Farmacopéia Brasileira, Vol. 2, 5a. Ed., Anvisa: Brasília, 2010.

${ }^{23}$ Barros Neto, B.; Scarminio I. S.; Bruns, R. E.; Como fazer experimentos: pesquisa $e$ desenvolvimento na ciência e na indústria, 6a Ed., Editora da UNICAMP: Campinas, 2006.

${ }^{24}$ Draper, N. R.; Smith, H.; Applied Regression Analysis, $3^{\text {rd }}$ Edn., Wiley: New York, 1998.

${ }^{25}$ IUPAC. Nomenclature, symbols, units and their usage in spectrochemical analysis - II. Data interpretation. Pure and Applied Chemistry 1976, 45, 99. [CrossRef] 